\title{
SOME STEPS IN THE EVOLUTION OF SOCIAL OCCUPATIONS.
}

II. FOOD.

Hunger never fails. All other appetites have their periods of activity and stagnation; passions wax and wane; emotions are casual and capricious. But the continuous discharge of the function of nutrition is interrupted only by the final interruption - death.- Henry Drummond, The Ascent of Man, p. 200.

Hunger has ever been and doubtless ever will be the most permanent impelling force of mankind. It was the sole stimulus to the earliest occupations and still operates as a most powerful motive in determining the activities of the race. No occupations affect the lives of individuals so closely as those which are devoted to supplying man with food. No others are so fundamental to the various forms of institutional life.

So potent a factor is food in the early development of mankind that it is almost possible to write the history of a people from a knowledge of the foods that they ate. When this is supplemented by. a knowledge of their manner of eating, we have a very good index of their culture. The late Professor Brinton regarded food as a most important factor in determining the destinies of people ${ }^{x}$. He stated that differences in races depend essentially upon those differences in organic development which result from differences in nutrition.

Coincidences in the Genesis, the Exodus, and the Leviticus traditions of different peoples are traceable ultimately to a similarity in their methods of procuring food. Differences in the same are likewise traceable to fundamental differences in these methods. Although it would be an extreme position to state, as some authorities do, that there is no activity in life that cannot be traced back to the food-process, there is a truth in the statement that it would be well for all to recognize.

The most important question of primitive man is not what to eat; that question is decided by the resources of his environ-

I Daniel G. Brinton, Races and Peoples, pp. 40, 4 I. 
ment. It is, rather, how to get possession of those materials which, though present, baffle his power to control. His difficulty was greater than that of the animals. The food of the lower forms of animal life is brought to them. They have merely to appropriate it as it comes. But with advance in complexity of structure, the difficulty of procuring food increases. So great is this difficulty that in the higher forms of animal life each species has solved the problem by setting aside certain organs to be devoted chiefly to this task. Animals have solved the problem of procuring food by changing the very texture of their tissues. Man alone has worked out a somewhat different method. The superiority of man's method consists not in a change in bodily tissues alone, nor in a more skilful use of any bodily organ, nor even in the mere use of a great variety of bodily movements, but in the subordination of the entire body to the service of the mind.

In this study let us attempt to discover the way in which man acquired, through the pursuit of the simple occupations of every day life, not merely free hands, but a free mind. Let us seek to discover how man developed himself through his occupations, and when we have learned the lesson, let us not merely seek to apply it in adjusting the conditions that shape our own lives, but let us secure such conditions in our public schools as will contribute to the most normal growth of the child.

It would be impossible, in the present state of knowledge, to trace the complete evolution of any occupation from its earliest inception to the latest step in its development. For a time, at least, we must content ourselves with considering.such steps in the process as we are able to determine, trusting that at some future time the mists which now obscure great regions of the past may be dispelled by the light that comes from the introduction of more and more refined methods of research. In turning our attention to those occupations which arose in response to the need of food, the following outline, which is a slight adaptation of one that 1 have used in another place for a different purpose $^{x}$ may serve to indicate, in a general way, the stages

'The Place of Industries in Elementary Education. Chicago: The University of Chicago Press. 
of development through which any occupation that keeps pace with the general advance passes through. Knowing that agriculture and domestic service are belated forms of industry, it may prove interesting to seek to discover what the conditions were which retarded their development and how more normal conditions may be secured.

\section{EPOCHS OF INDUSTRIAL DEVELOPMENT.}

I. The house industries or the period of domestic economy.

I. The hunting stage.

(a) The river-drift people.

(b) The early cave-dwellers. Pleistocene period.

(c) The later cave-dwellers.

2. The fishing stage.

3. The pastoral stage.

4. The agricultural stage.

5. The age of metals.

(a) The age of copper.

(b) The age of bronze.

(c) The age of iron.

6. The city-state.

7. The feudal system.

II. The handicraft system or the period of town economy.

Prehistoric period.

III. The factory system or the period of national economy.

Historic period.

In order to facilitate the process of forming sequences which shall embody the cumulative results of the entire study, the occupations of each period will be considered with reference to such topics as are included in the following outline:

OUTLINE FOR THE STUDY OF A PARTICULAR PERIOD.

I. The people: Their equipment at the beginning of the period under consideration.

II. The character of the area inhabited with reference to its fitness for supplying an abundance and a suitable variety of nutritious foods.

III. The processes involved in the satisfaction of the need of food.

r. Production.

(a) Production of raw materials.

(r) Processes.

(2) Motive power.

(3) Mechanical appliances. 
(b) Manufacturing.

(I) Processes.

(2) Motive power.

(3) Mechanical appliances.

(c) Distribution and exchange.

(I) Processes.

Storing.

Preserving.

Carrying.

Trading, et cætera.

(2) Motive power.

(3) Mechanical appliances.

(2) Consumption.

(a) Processes.

Cooking. ${ }^{x}$

Serving.

Sanitation.

(b) Motive power.

(c) Mechanical appliances.

IV. Influence of foods and the occupations which are associated with them upon the individual and the social development of the people.

V. Educational opportunities presented by the occupations of the period.

I. Practical activities of value for educational purposes. Significance of [each with reference to-

(a) the physical development of the child.

(b) the intellectual development of the child.

(I) As a means of securing a free play of mind.

(2) As a means of laying the foundation of the physical, natural, and social sciences, and the arts.

(c) the development of the ethical nature.

2. Suggestions regarding the use of these materials in the different grades of the elementary school.

Remains of river-drift peoples have been found in various parts of the world. Although these remains are meager, the combined efforts of the anthropologist, the archæologist, the paleontologist, and the geologist have enabled us to reconstruct, within fairly definite limits, the life of the period. The fact that remains which have been referred to the early part of the mid-Pleistocene period are found in widely separated regions, indicates that many parts of the earth were occupied by man in that remote

I The question may well be raised whether cooking should be considered under the processes of production or consumption. 
time. Similarities in the skeletons and implements that have been found indicate to some minds a common origin and cradleland and a subsequent dispersal; to others they indicate merely similarity in structure and in conditions of life.

Our race is made up of many elements which for long ages remained in a plastic condition. The nomadic form of life supported by such universal customs as exogamy, and the various forms of conquest, resulted not merely in a transference of peoples from one locality to another, but in a gradual assimilation of peoples. There are doubtless many cradle-lands of our race. The habitable regions of Europe, during that long period which preceded the prehistoric epoch, were all occupied at various times by scattered populations. There are many reasons for believing that the river-drift people, who occupied western Europe during the early part of the mid-Pleistocene period in company with the mammoth and the cave-bear, form one of the constituent elements of our race. The appearance throughout each period of historic times of a physical type similar to that of the skeletons that have been referred to this period certainly points in that direction. For the purposes of this study, however, it is sufficient to recognize the fact that even though the particular people just referred to may not form an element of our race, our forefathers, in their earliest state, must have lived under similar conditions and occupied themselves in much the same way.

The skeletons that have been found show that the river-drift people were short but powerfully built. They must have walked with a bend at the knee, for their thigh-bones were curved in a curious way. Their skulls were long and depressed and were marked with strong brow ridges. Their jaws were massive and powerful, the lower-one sloping downward and backward on account of the absence of the chin prominence.

From the results of the study of comparative anatomy, ${ }^{x}$ we may conclude that the great toe was shorter and smaller, the heel bone less strongly made, and the arch of the foot much flatter than it is in modern types. The river-drift man undoubt-

${ }^{x}$ Frank BAKer, The Ascent of Man. Smithsonian Report, I890. Pp. 447-66. 
edly had greater control over the movements of the toes than modern man, and less control over the smaller muscles which control the movement of the arm and hand. In fact, man's hands were not yet free from the function of locomotion, for he had not yet secured dominion over fire, which later afforded him protection from the beasts of prey. Accordingly the trees offered him the safest places of refuge; and he no doubt found it more prudent to swing from branch to branch, as he exploited his environment in search of food, than to expose himself to danger by walking upon the ground. It is this fact rather than kinship with the apes, which has caused the river-drift people to be called tree-dwellers.

As long as man was obliged to seek protection in the trees, he must have had difficulty in maintaining an erect posture. Indeed it is only with difficulty that civilized man can maintain an erect posture for a prolonged period. Yet he has a great advantage over the river-drift man; for the large muscles of the back, the buttock, and the calf of the leg, which are necessary in order to maintain an erect posture, were not well developed in that early age.

The inferiority of the river-drift man was due more-to his lack of discipline and experience than to any inherent quality. His brain capacity was nearly equal to that of civilized man. He was limited in his resources, because he had to work out his problems from the beginning. He was at the short end of the lever. Only gradually did he become conscious of his own power; but as he did so, he laid the foundation, slowly but surely, of much of that which, in a more highly developed form, we prize in our life today.

The geography of Europe during the Pleistocene period was different in many respects from what it is at present. There were differences in the courses of rivers and in the contour of the continent. The land that now constitutes the British Isles at that time was a part of the mainland. The climate, during the early part of the period, was but little removed from the tropical, presenting neither extremes in heat nor in cold.

The prevailing animals were those which now characterize 
unsettled regions in tropical and temperate climates, together with several species which have since become extinct, and the musk sheep and the woolly rhinoceros which came down from the North during the mid-Pleistocene period. There was surely a sufficient variety in the animal kingdom, and man soon learned ways of compelling the less formidable creatures to pay tribute to his most pressing need.

A considerable variety, too, was offered by the vegetable kingdom; but it did not offer food-stuffs in such an abundance as to deprive man of the stimulus that comes from the struggle for existence. The plains and uplands, which were covered with wild grasses, afforded a plentiful supply of food for the grasseating animals, but were not suited for human habitation at this time. Man had not yet learned to capture the wild beasts, and his digestive system, though frequently called upon to perform marvelous feats, was not equal to the task of transforming grass into nutritious materials in sufficient quantities to enable him to maintain the struggle for life. For this reason, as well as on account of the fact that the river-drift man who exposed himself to the dangers of a grassy plain was apt to become the food of some wild beast, the grassy plains were avoided by man at this time.

The safest regions for the river-drift people to inhabit were well-wooded ones; but there were differences in these of the greatest import with reference to the human life of the time. Dense forests have never offered a sufficient inducement to savage peoples to cause them to become thickly populated. The difficulties that they present are such as to baffle the powers of people who have not made considerable advance in the mechanical arts as well as in the arts of living and working together. At this early date, when the water courses had not been cleared of natural obstructions, the dense forests along their middle and lower courses partook too much of the nature of malaria-breeding swamps to permit man to inhabit them, even though they had offered him a sufficient inducement in the way of nourishing foods. But it is not in the dense forests that man finds wild foods most easily. The thick foliage of the trees 
obstructs the passage of the sun's rays and interferes with the development of nutritious roots, bulbs, nuts, and berries, which everywhere occupy an important place in the domestic economy of primitive peoples.

Repelled alike by the grassy plains and the dense forests, the river-drift people were attracted by the resources of the wooded hills near a river, a lake, or a spring of fresh water. Some well-known authorities still believe that man's earliest home was upon the seashore. Though that may be true, this study, which is based upon the records that have thus far been discovered, must begin with the life of man upon the wooded hills. These wooded hills of western Europe, which afforded available food supplies, as well as protection, were undoubtedly the cradle-lands of our race. Under the stimulus of hunger, the river-drift man exploited the resources of the wooded hills. The oak trees yielded acorns, the evergreens bore seeds, the wild plums offered their bitter fruit. Wild peas and beans, seeds of various kinds, leaves, especially the thick leaves of the wild cabbage, and several varieties of wild berries could be gathered at different seasons of the year. Imbedded in the earth, there were the stringy-rooted carrots, ruta-bagas, and turnips. So far as man was able to appropriate these materials of the vegetable kingdom to his own uses, they became elements in his food supply. The animal kingdom, too, very early was compelled to pay man tribute. The way in which man gradually rendered the various resources of the wooded hills available for human needs is the first chapter in the evolution of social occupations. It is this subject to which attention is next invited.

The University of Chicago.

Katharine E. Dopp. 